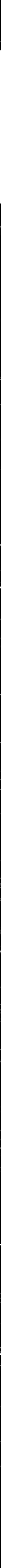


This report was prepared as an account of work sponsored by an agency of the United States Government. Neither the United States Government nor any agency thereof, nor any of their employees, makes any warranty, express or implied, or assumes any legal liability or responsibility for the accuracy, completeness, or usefulness of any information, apparatus, product, or process disclosed, or represents that its use would not infringe privately owned rights. Reference herein to any specific commercial product, process, or service by trade name, trademark, manufacturer, or otherwise does not necessarily constitute or imply its endorsement, recommendation, or favoring by the United States Government or any agency thereof. The views and opinions of authors expressed herein do not necessarily state or reflect those of the United States Government or any agency thereof.

\section{REMOTE MONITORING OF MOLTEN RADIOACTIVE GLASS (U)}

by

R. F. Schumacher' ${ }^{1}$ K. K. Li ${ }^{2}$, and A. Schneider ${ }^{3}$

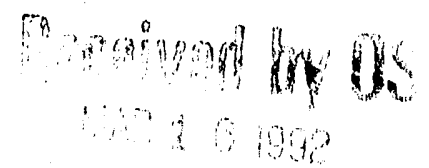

${ }^{1}$ Westinghouse Savannah River Company

Savannah River Site

Aiken, South Carolina 29808

${ }^{2}$ Georgia Institute of Technology

Nuclear Engineering Program

Atlanta, Georgia 30332

${ }^{3}$ Massachusetts Institute of Technology

Department of Nuclear Engineering

Cambridge, Massachusetts 02139

A paper proposed for presentation at the

$X V$ International Symposium on Nuclear Waste Management

Strasbourg, France

November 4 - 7, 1991

and for publication in the proceedings

This report was prepared in connection with work done under Contract No. DE-AC09-89SR 18035 with the U.S. Department of Energy. By acceptance of this report, the publisher and/or recipient acknowledges the U.S. Government's right to retain a nonexclusive, royalty-free license in and to any copyright covering this report, along with the right to reproduce and to authorize others to reproduce all or part of the copyrighted report. 
REMOTE MONITORING OF MOLTEN RADIOACTIVE GLASS

ALFRED SCHNEIDER

MAsSACHUSETTS INSTITUTE OF TECHNOLOgY, DEPARTMENT OF NUCLEAR ENGINEERING, 24-109B, CAMBRIDGE, MA 02139

KANG-WEN K. LI

Georgia institute of technology, nuclear engineering program, ATLANTA, GA 30332

RAY F. SCHUMACHER

Westinghouse Savannah River Company, Savannah River laboratory, AIKEN, SC 29802

XV INTERNATIONAL SYMPOSIUM

ON THE

SCientific Basis for nuclear waste Management

NOVEMBER $4-7,1991$

StRASBOURG, FRANCE 
REMOTE MONITORING OP MOLTEN RADIOACTIVE GLASS

\begin{abstract}
ALPRED SCHNEIDER* KANG-MEN $K$, L $I^{* *}$, AND RAY $P$. SCHUMACHER * *
Massachusetts Institute of Technology. Department of Nuclear Engineering. 24-109B, Cambridge, MA 02139

* Georgia Institute of Technology, Nuclear Engineering Progran, Atlanta, GA 30332

* Westinghouse Savannah RIver Company, Savannah RIver Lab. Alken, SC 29802
\end{abstract}

\title{
ABSTRACT
}

An on-1lne method is described for the near-continuous monitoring of the composition of a molten radlooctlue waste glass or. alternatively, for signaling a deviation from the target composition of waste glass. The principle of thi. method, proposed by A. 8ctinalder In 1086, ls founded on the ralation between two opecific physical propesiles and composition in a ternary system. Most glasues cursently consldered as wate forms can be represented as poeudo-ternary system. The palrs of properties especially sulted for this purpose are viscosity/density and viscosity/electrical conductivity. A novel viscometry method was developed whlch uses the remotely deternined rise velocity of carefully metered gas bubbles. The monitoring method was tested successPully with simulated Savannah River waste glasses. An integrated probe was concelved for a Joule-heated melter for the on-line deternination of viscosity, temperature, density, and llquid level. A computer progran calculates the glase composition from the measured data, using information from a previously developed data base.

\section{INTRODUCTION}

Glass has been the preferred waste form in many countries practicing or contemplating the solidiflcation of high-level liquid radioactive wastes. Borosilicate glasses have generally been selected because of their relative chemical stablifty, capablilty of incorporating varlous elements and compounds, and long production experience.

The propertles of a waste glass are determined prinarily by 1 ts composition, ope:ating variables during production, and the cooling rate after the glass is poured into the canisters. Leachability, the property of paranount. importance, depends greatly on the chemical composition of the waste glass. Great care is taken during the design and construction of vitrification facllities to allow for very precise compounding of the ingredients and for the continuous monitoring of the operating variables. At present, the conforwance with composition specifications can only be verlfled by perlodically withdrawing a molten glass sample whlch is then analyzed in a remotely operated analytical facility. Plgure 1 is a schematic diagram of the glass sampler for the Savannah Rlver DWPF melter. It replaces the usual connector between the pour spout and the canister top. since only infrequent sample withdrawal is planned. The sampling, sample transport, and chemical and phystcal analyses are cumbersome operations because of the complexity of the remotely operated equipment and several days will be required to complete the necessary tests. While these tests are important for the waste qualification protocol. they are of lialted value for controlling the continuous glass production process. The application of continuous monitoring methods practiced in the chemical process industry would be very difficult in this instance, because of the large number of chemlcal elements contained in the glass and the extremely hostile environment of high radiation and elevated cemperature. 
However, the glass composition can be estimated with sufflcient accuracy from the deteralnation of certaln physical propertieg which can be done by remote means $[1]$.

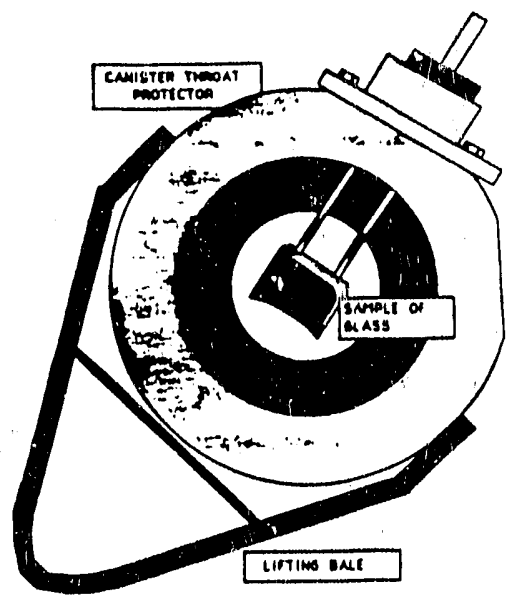

Plgure 1. Savannah River DWPF molten glass sampler

ESTIMATION OP GLASS COMPOSIIION

\begin{abstract}
Trlangular phase diagrams are useful in representing properties of ternary compounds as well as more complex systems which can be approximated as pseudo-ternary compounds. The propertles of borosillcate glasses are conveniently represented on a ternary diagram as a function of $\mathrm{s}_{10} \mathrm{O}_{2} . \mathrm{Na}_{2} \mathrm{O}$, and $\mathrm{B}_{2} \mathrm{O}_{3}$ concentrations. Variation of speciflc physical properties with compos!tion can be shown, for example, es constant value lines for a given temperacure (fsoplethis) as lllustrated in Pigure 2 for daca found in the literature. By determining two physical properties at the same temperature, one can estinate the corresponding composition for the point where the two lisopleths intersect. The precision with which the composition point is located is enhanced if the loopleths do not intersect at anall angles. It can be seen in Plgure 2 that melt viscosity, electrical resistivity, and density are composition dependent but to a decreasing extent, respectively. It is also apparent that viscosity/density and viscosity/electrical resigtivity are sultable pairs, while the electrical resistivity/density combination would produce a large wargin of error in the derived compositions.
\end{abstract}
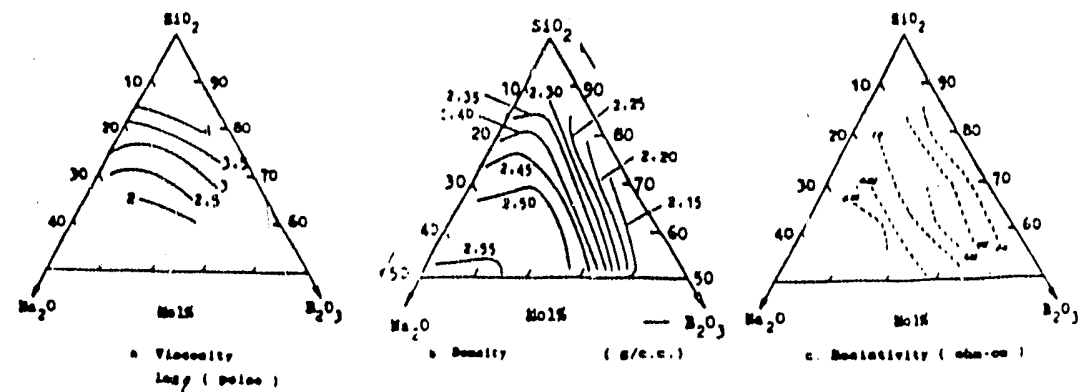

Plgure 2. Isopleths for sodium borosillcate glass at $1100^{\circ} \mathrm{C}$ 
The computer program TERNARY written by Kwansik Choi in Portran was used to estimate the borosjlicate glass composition from two physical properties at. a given temperature [2]. In this progran polynomial equations are fitted to the lsopleths by the least square method. Speciflc compositions which cor-. respond to the roots of the equations representing the pairs of property values are then obtained, using the Newton-Raphson method. The progras was tested with data from the literature for sodium borosllicate glases. The results shown in Table I indicate a favorable comparison between the composition for which the physical properties were selected and the composition calculated with TERNARY.

TABLE I

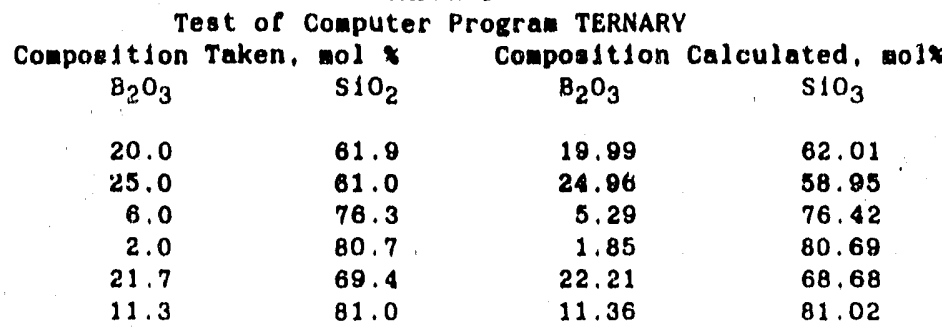

A systematic investigation of the effects of varlations in composition on certain propertles of the Savannah River maste glass was carried out by Schumacher [3]. A simplifled schematic diagram of the overall process which will be used in the Defense Waste Procesoing Pacllity (DWPF) is shown in Pigure 3. The foed to the melter consists of three components: sludge (the insoluble portion of the orlginal neutralized high-level waste composed of the hydroxides of $\mathrm{Pe}, \mathrm{Al}, \mathrm{Mn}, \mathrm{N} 1$ and contalning nost radioactive nuclides), PHA (precipitated hydrolysis aqueous product), and Prit 202 (a crushed and classlfled glass containing $\mathrm{B}_{2} \mathrm{O}_{3}, \mathrm{~L}_{2} \mathrm{O}, \mathrm{MgO}, \mathrm{Na}_{2} \mathrm{O}$, and $\left.\mathrm{S}_{2} \mathrm{O}_{2}\right)$. While the non-volatlle compositions of the three components will remaln fairly constant over extended perfods, some varjabllity is expected in the ratjos between the sludge, PHA, and frlt which would cause some devlation from the target composition of 28 wt: 8 ludge, 8 wt* PHA, and 64 wt* frlt.

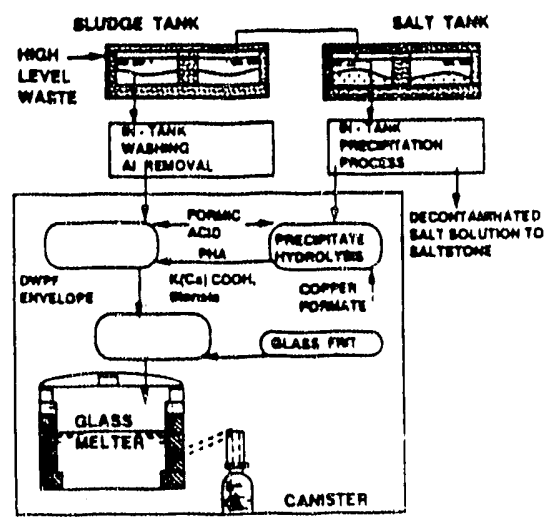

Figure 3, Simplif led schematic of the Savannah Rlver HLLW treatment process

Mejt viscosities at $1150^{\circ} \mathrm{C}$ and densities at room temperature for annealed glasses were obtalned for twenty one glass melts. It is evicient from plgure that the relative orjentations of these jsopleths are very favorable for lhe proposed monltaring method. 


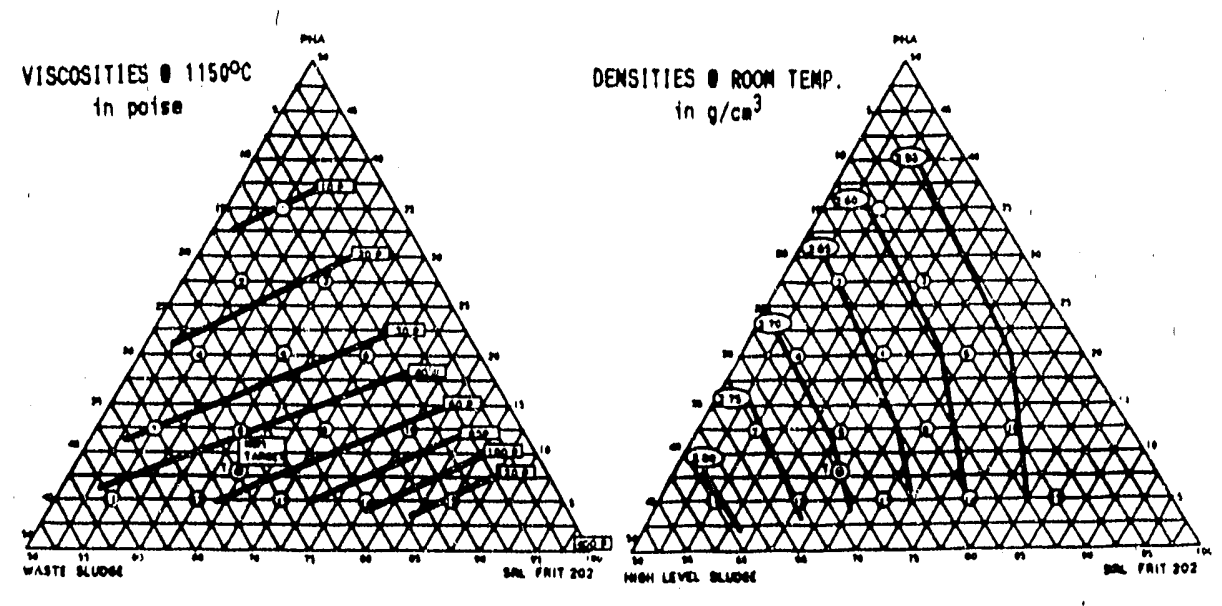

Plgure 4. Melt viscositles and denalties of DUPP glass

\section{MEASUREMENT METHODOLOGIES}

Many methods are avallable for llquid visconetry, but the elevated temperature and the corroslveness of the molten glass have generally liulted the cholces to the falling ball, flow rate through an oriflce, and rotating spindle methods (Brookfleld type vlacometers). It became evident at the outset of thls study that none of the above wethods would be gultable for the continuous monitoring of molten glass. especially for remote operation in an intense radloactlue fleld. A new viscometry method was developed which 18 based on the rise velocity of gas bubbles.

It was known that the rise velocity of gas bubules in a liquid is a functlon of the densitles and viscositles of the gas and the liquid, the diameter of the gas bubble, and the gravitatjonal constant (stokes or Hadamard-Rybczynskl (ormulae), Other factors, such as changes in shape and slze of the ascending bubble (due to diffusion, chesical reaction, decreasing hydrostatic pressure, and temperature), the surface tension at the gas-1lquid interface, and the geometry of the liquid container (wall-effect) will also affect the rlse velocity of the bubble, but these effects can be ininized by proper selection of the gas and of the distance over which the bubble velocity is determined.

The experimental setup, shown schematically in igure 5 , consisted of a hellum bubble generator which releases apecifled mass of hellum; two dellvery tubes placed so as to release the bubbles at different levels; a system for detecting the arrival of the hellum bubble at the liquid-air intersace; and a personal computer for controlling the bubble generation and launching cycles, data manament (acquisition, processing, and archiving), and dlagnostlcs. The pressures in the launch tubes were measured with transducers and the temperature in the vicinity of the bubble path was deterwined with a thermocouple. The bubble generator, hellum detector, and computer were located several meters from the liquid contalner.

In the first phase of this study, the system was tested with Cannon Instrument Company s-2000 and $s-8000$ high viscoslty olls (polybutenes). Within the teuperature range over which the system was tested $\left(20\right.$ to $\left.50^{\circ} \mathrm{C}\right)$ the $v 1 \mathrm{~s}$ cosities varled between 10 and 38000 centipolse. In the second phase, bubble rlse velocitles mere obtalned for simulated Savannah RIver waste glass over a temperature range of 1020 to $: 100^{\circ} \mathrm{C}$. The molten glass was contalned in Coors 


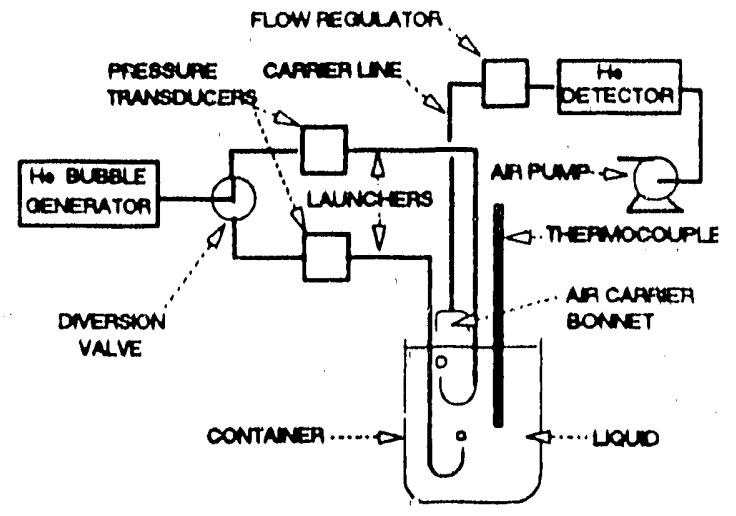

Plgure 6. Schenatic of remote monltorlng laboratory syatem.

alumina cructoles placed in a Lindberg high-temperature furnace provided with a Eurother 818 communicating temperature controller; the bubble launchers and the thermocouple protectlve tubes were made of inconel. The bubble diameters ranged from 0.8 to $2 \mathrm{~cm}$, converted to standard temperature and pressure.

The valldation of the BRV visconetry method was made by comparison with data obtalned by standerd viscometry methods: Cannon-Penske viscometers for the $\mathrm{s}-2000$ and $\mathrm{S-8000}$ olls (reference viscosities at $25^{\circ} \mathrm{C}$ were 57 and 240 polse, respectively) and Brookfleld type instrument wh a platinum rotating spindle for the glass (reference visuosity at $1050^{\circ} \mathrm{C}$ was 85 poise). The plots presented in Pigures 6 show an excelient correspondence.
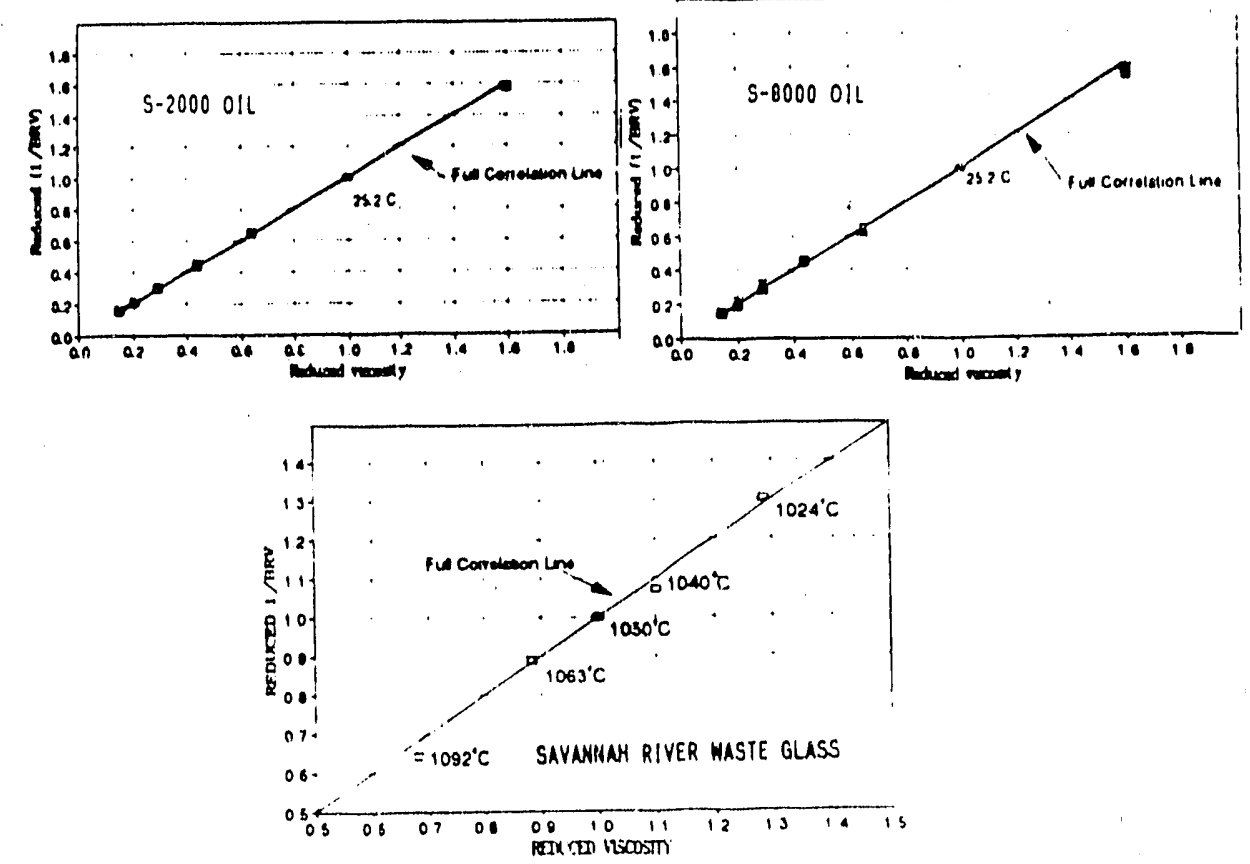

Pigure 6 . Comparison of reduced (1/BRV) and reduced viscosities 
The dens lties of the liqulds were obtalned from the pressures measured at the instants of bubble launchings which are the hydrostatic pressures at two levels separated by a known dlstance. The results are shown in Plgure 7 .
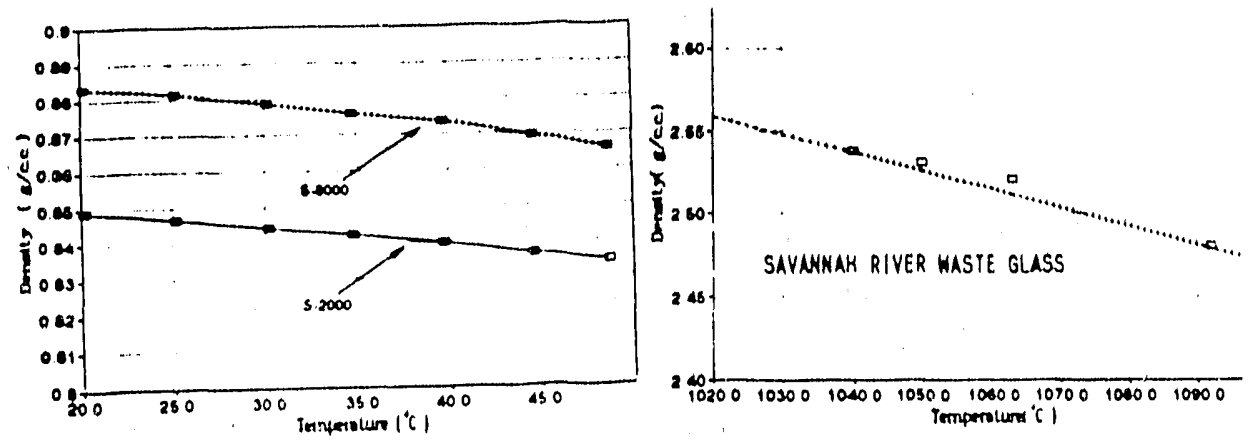

Flgure 7. Densttles obtalned by rewote measurement

The following emplrical formula, derlved from geveral hundred data points, permits the caloulation of the dynamic viscosties from BRV measurements, taking into conalderstion the bubble dlameter, the liquld contalner dianeter, and the liquid density [4]:

$$
\begin{aligned}
& \eta_{\text {aRV }}=\frac{100(\rho / B R V)}{4.1122 D_{b}^{-1.41 s 1}\left(D_{b} / D_{c}\right)+0.9813 D_{b}^{.2 .8 n}} \\
& \text { Applicab/11ty range: } 0.08<D_{b} / D_{c}<0.53 \\
& \text { where } \begin{array}{rlrl}
\eta_{\text {anv }} & =\text { vlscosity of the liquid } & & {[\mathrm{po} / \mathrm{se}]} \\
\rho & =\text { measured density of the liquid } & {\left[\mathrm{g} / \mathrm{cm}^{3} \mid\right.} \\
\mathrm{BRV} & =\text { measured butble rise veloclty } & (\mathrm{cm} / \mathrm{sec}] \\
D_{\mathrm{b}} & =\text { measured bubble diameter } & {[\mathrm{cm}]} \\
D_{\mathrm{C}} & =\text { measured inner diameter of container }[\mathrm{cm}]
\end{array}
\end{aligned}
$$

The visicosities determined with the BRV method and using the above formula agreed well with the data obtalned with standard visconcters. In the case of the Savannah River waste glass the standard error for a large number of deterninations was $\pm 6 x$.

CONCEPTUAL DESIGN OF A MONITORING SYSTEM

A concept for an Integrated probe for the remote monitoring of nolten glass which incorporates the features demonstrated in this study is shown in Plgure 8.

The probe made of Inconel 690 consists of two launch tubes, one thermocouple tube, and one gas sampling tube. The heavy duty Inconel 690 tubes are expected to withstand corrosion by molten glass and should not deform as a reault of the movement of the molten glass. The cover section of the probe is sindlar to those used for thermocouple wells and level dip tubes in existing melters. Plexible metal tubes with quick disconnects are used for all connections outslde the melter. The probe can be remotely replaced, should this becone necessary after the start of hot operations.

The bubble detection method used in this study would be sultable for certaln melter types, such as the current model for the West Valley Demonstration 


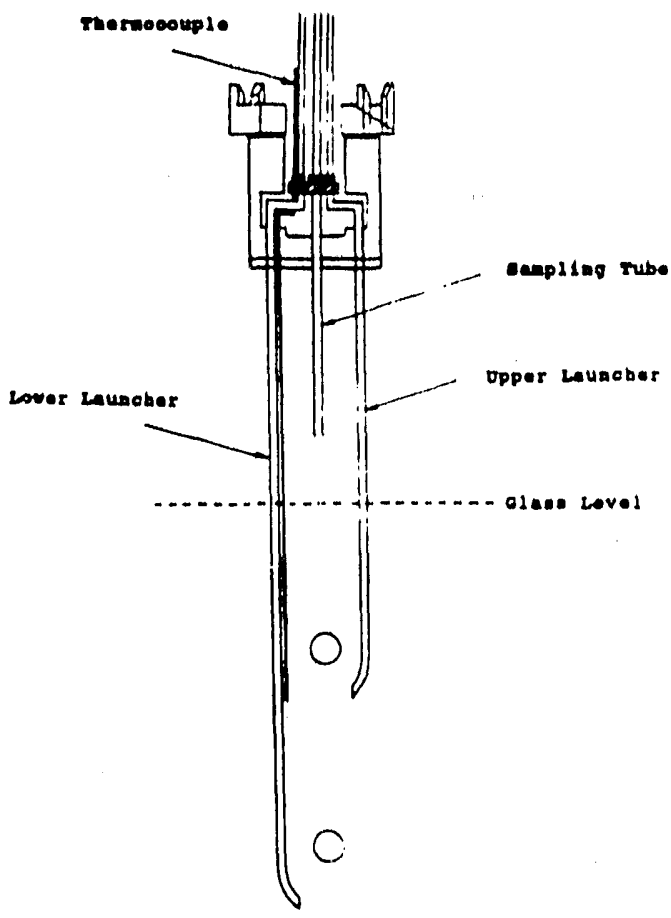

Plgure 8 . Concept for an integrated glass monltoring probe

Profect. Where the glass products is air-lifted from a compartment fllled by an underflow. Por other melters, such as the DWPF unit, the bubble detection method will be modifled to avoid interference with the bubble exit from the moltet glass which can be caused by the cold cap on the glass surface and by the much lower glass surface temperature due to the tempering effect of the evaporating water. The Instance at which the gas bubble reaches a certaln level can be conveniently determined with two electrodes with a small AC or $D C$ potential applied across them. The change in impedance will produce a change in the current and this signal can be processed in a.conventional manner. The principle of this detection method was desonstrated with glycerol rendered electrically conductlve by the addition uf a small amount of $1.1 \mathrm{Cl}$. The method is well sulted for molten glass which is a conductor and the electrodes consisting of inconel can be incorporated into the monitoring probe.

CONCLUSIONS

The compositlons of ternary or pseudo-ternary ixtures can be montored by frequent determinations of two physical propertles. In the case of molten waste glass, v1scosity and density are the propertles of cholce.

Bubble rise velocity viscometry was shown to be method comparable in precision and accuracy with established methods. This method is unlquely adaptable to remote operation and the only components in contact with the $11 \mathrm{q}$ uld being analyzed are passive metal tubes. Auxlllary components, which are susceptible to radiation damage, can be located at appreciable distances.

Concepts were developed for integrated monitoring probes compatible with melters of current design. These probes allow the near-continuous determiliation of viscosity, density, temperature, and hydrostatic pressure. Computer hardware and sof tware were adapted for data acquisition and processing, inter- 
face with process controls, and generation of arohlval materials for quality assurance.

\section{ACKNOWLEDOEMENTS}

Part of thls study was sponsored by E.I. du Pont de Nemours a Company and Westinghouse Savannah RIver Company, as contractors of the U.S. Department of Energy for the Savannah RIver site. The authors are grateful to Robert Abraham and $k$. Chol for thelr important contributions to the laboratory studies.

REPERENCES

1. A. Schneider, U.S. Patent Application No, 07/051,066 (1990).

2. A. Sohnelder, et al. PInal Report for Project E25-662, Georgla Institute of Technology, 1980 .

3. R,P. Schumacher, presented at the 93rd Annual Meeting of the Amerloan Ceranic Soclety, Cinclnnat1, OH, 1981.

4. K.K. L1, PhD Thes18, Georgla Instdtute of Technology, 1991. 

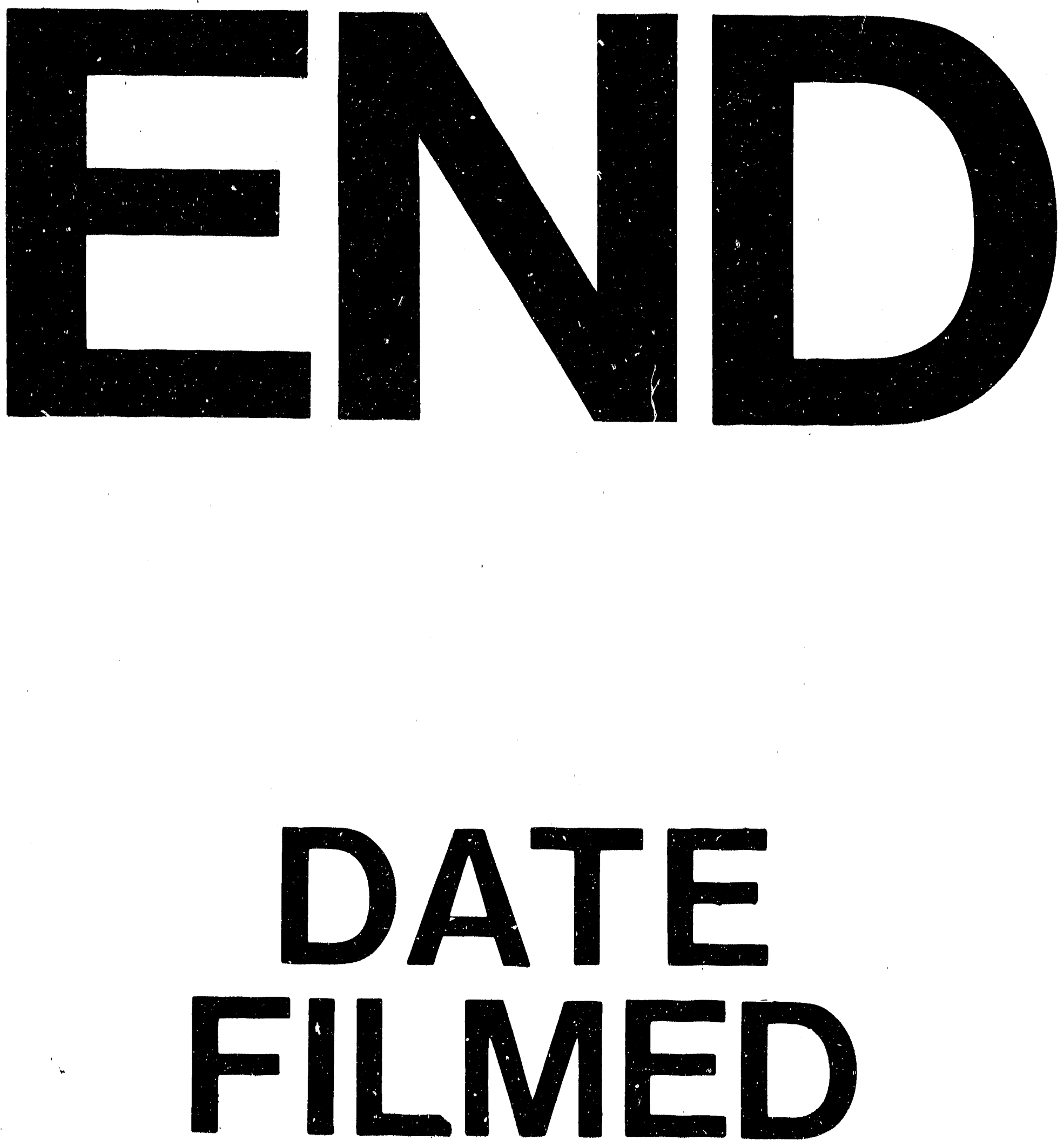

1

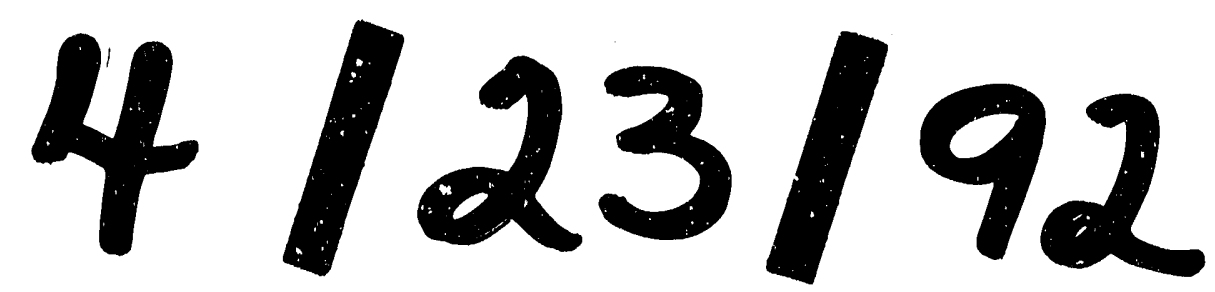


